\title{
Editorial
}

\section{Integration of Knowledge: The Continuing Challenges}

\section{Ssekamanya Siraje Abdallah ${ }^{\mathrm{a}}$}

While concern with the issue of educational "dualism" and the need to Islamize contemporary human knowledge and integrate it with revealed truth was the preserve of western-educated Muslim intelligentsia in the 70 's, it has become the concern of educators and other stakeholders of educational systems throughout the world. The growing numbers of Muslims in non-Muslim majority societies have raised concerns about the treatment of matters of the Islamic faith in public school systems (Triki-Yamani \& McAndrew, 2008). The political events in the world since the September 11 tragedy have made focus on integration even more urgent (Malkawi, 2012). While the efforts of the pioneers of Islamization of knowledge were focused on higher education, more and more researchers are paying education to the primary and secondary levels.

The first article in this issue, by Mohd. Suhaimi bin Haji Ishak and Sohirin Mohamad Solihin, is a historical analysis of the contributions of Mohammad Natsir, one of the greatest educational thinkers in Indonesia, to the idea of "integration of knowledge" long before the Makkah conference. Beginning with a brief review of the life and works of Mohammad Natsir, the authors analyse his discomfort with western education, especially as it was practiced by the dutch colonialists in Indonesia. Nevertheless, he was objective enough to

a Kulliyyah of Education, International Islamic University malaysia, Email: siraje@iium.edu.my 
recognize the superiority of western education in equipping youth with advanced technological and analytical skills. Thus the solution was not to shun western education but to find a way of integrating it with the religious beliefs and cultural practices of Indonesians. His ideas of integration were embodied in special integrated schools that could be considered the precursors of Indonesia's integrated model of modern religious schools (Pesantren Moden).

The second article, by Ahmad Tijani Surajudeen and Muhamad Zahiri Awang Mat, is an empirical assessment of the integration of knowledge in Nigerian schools. Based on a survey of 344 students from integrated Islamic schools in the majority-Muslim North-Central Nigeria, it was found that schools are making palpable attempts at integrating Islamic and contemporary human knowledge. Nevertheless, the respondents expressed some level of dissatisfaction with the pedagogical approaches used in the Islamic schools, leading the authors to conclude that the integration efforts should not be limited to the curriculum but should include everything that can help Muslim children to acquire modern sciences and technologies and be competitive in the global market place, while being equipped with Islamic knowledge and values.

The third article, by Adan Saman Sheikh, looks at the issue of integration from a different angle. While many people start with the need to infuse Islamic curricula and values in modern, Western-type schools, the situation in Kenya is the reverse. Adan argues that, as is the case with many Muslim societies colonized by western powers, Kenyan Muslims were left behind in terms of modern education. Out of fear of the Christianization tendencies of modern schools, most parents send their children to Qur'an schools where only religious studies are taught. Those who wanted to equip their children with modern knowledge and skills had to send make their children attend both systems concurrently, with very high drop-out rates. In addition to the historical analysis of the trends of Muslim education in Kenya, the author conducted an empirical case study of a new model of "Integrated Schools" where children have access to both the modern secular and Islamic sciences under one roof. He concludes that the Integrated model has been so successful that even the non-Muslim Kenyan government has passed legislation to make it one of the strategies for increasing the access of Muslims and other minority groups to education. 
Putting the issue of integration of education aside, the fourth paper, by Kazeem Oluwatoyin Ajape, Arifin Mamat, Ismail Sheikh Ahmad, and Ismail Hassanein Ahmad, discusses the motivation of Arabic as a Second Language students. Using the Attitude Motivation Test Battery (AMTB), data were collected from 288 Arabic language students from six Nigerian universities. Results showed low levels of motivation to learn the language that could be ascribed to pedagogical practices among the instructors and lack of availability of suitable jobs upon graduation. Considering mastery Arabic is a major element in efforts to integrate Islamic revealed knowledge with modern man-made disciplines, concerted efforts are needed to produce teachers that are not only competent in the language and equipped with appropriate pedagogical skills but also possess the right attitude and motivation to learn the language and teach it to others.

The fifth paper, by Mukhtar Alhaji Liman and Yusuf Ismail examines three aspects of Bloom's taxonomy of educational objectives and how they relate with students achievement in learning mathematics. Data collected from 250 students were analyzed using Exploratory factor analysis and Structural Equation Modeling. It was found that the three dimensions of the cognitive domain tested in the model, namely, remembering, understanding, and applying, positively and directly influenced mathematics achievement. While Bloom's taxonomy has been used by educators for a long time, newcomers may not realize how these issues remain relevant today.

The sixth paper by Ruqiyyah Numan discusses the important issue of quality assurance in Muslim higher education. While most scholars of Islamization and integration of knowledge have focused on the contents or curricula of eduation, Ruqiyyah argues that the organization of education systems in Muslim societies needs to be Islamized. She questions the appropriateness of using imported standards, goals and outcomes in educational quality assurance. Just like Islamization of curricula, the solution she suggests involves understanding the basic tenets of Islam and making them the foundations for quality assurance. Modern standards and outcomes that are in line with the teachings of Islam should be adopted while those that are contrary to the teachings of Islam should be rejected. 
The volume ends with a review of The Internationalization of East Asian Higher Education: Globalization's Impact, edited by John D. Palmer, Amy Roberts, Young Ha Cho, and Gregory S. Ching. The reviewers, Tareq M. Zayed and Hairuddin Mohd Ali, posit that the chapters in this volume are timely and important contributions to the exposition of developments in the internationalization of higher education in this region. Countries like Malaysia, Singapore, Thailand and Indonesia, have seen rapid increases in number of international students. This needs to be carefully managed in order to yield the envisaged positive outcomes for the countries concerned.

\section{References}

Malkawi, F. (2012). Issues of Integration of Knowledge in the Field of Islamic Studies. Lecture delivered at the Academy of Islamic Studies, University of Malaya, Kuala Lumpur, Malaysia. Retrieved on 30th June 2015, from http:/www.iiit.org/NewsEvents/News/tabid/62/articleType/ArticleView/ articleId/258/Default.aspx

Triki-Yamani, A. \& Mc Andrew, M. (2008). Islam and Education in Pluralistic Societies: Integration and Transformations. Report on Workshop held at the University of Montreal, Montreal, Canada, 6-9 May 2008. 